\title{
Psychological Compassion as Portrayed in Dorothea in Eliot's Middlemarch and Louisa in Dickens' Hard Times
}

\author{
Ali Mahmoud Ali Alshwayyat \\ Faculty of Languages and Communication, Universiti Sultan Zainal Abidin, Terengganu, Malaysia \\ Mohd Nazri Latiff Azmi \\ Faculty of Languages and Communication, Universiti Sultan Zainal Abidin, Terengganu, Malaysia \\ Isyaku Hassan \\ Faculty of Languages and Communication, Universiti Sultan Zainal Abidin, Terengganu, Malaysia \\ Khaled Ahmed Hmoud Alamro \\ Faculty of Arts and Sciences, Middle East University, Amman, Jordan \\ Mahameed Mohammed \\ Faculty of Arts and Sciences, Middle East University, Amman, Jordan \\ Rashed Ahmad Daghamin \\ College of Arts and Sciences, University of Hail, Saudi Arabia
}

\begin{abstract}
This article has a cogent argument to investigate the similarities and differences between Eliot and Dickens' techniques in revealing the insight natural expressions of compassion by analyzing the heroines' characteristics portrayed in the common theme of their selected novels. This article adopts the Seven-Stage Model of Maslow's (1970) Motivation Theory to analyze Dorothea in Eliot's Middlemarch and Louisa in Dickens' Hard Times. According to Maslow, individuals should satisfy the models' conceptual expressions completely to reach an ultimate level, which is self-actualization needs. In this regard, Maslow maintained that those who have reached the pyramid's peak are capable of love. The findings of this study indicate that Eliot shines by enhancing many prominent feminine touches, emotional and aesthetic concepts, and passionate experiences in her heroines' personalities much more than Dickens who ignores them. For instance, Dorothea in Eliot's Middlemarch satisfies all the conceptual expressions of the model's self-actualization needs perfectly, while Louisa in Dickens' Hard Times has many problems, particularly in getting love, esteem, as well as cognitive, aesthetic, and self-actualization needs. So, Eliot's excellence suggests a powerful contribution by refuting and criticizing the Victorian masculine stereotypical mottos that women could not express more than half of life and they could not feel a passion.
\end{abstract}

Index Terms — compassion, Hard Times, Middlemarch, psychology, Victorian era

\section{INTRODUCTION}

First of all, in the Victorian age, the great age of English novels, Victorian literature became very important and powerful because it relied on a realistic model of representation. Almost most writers played an honorable role in picturing what had taken place during that period, especially how much women struggled to take their justice and legality. It is worthy to recognize that during the Victorian period, women did not have many rights to live as ideal ones because men did not believe that women could express more than half of life and could not feel passion, ambition, anger, or honour (Showalter, 1977). Besides, many women were treated as inferior to men. According to Gallagher (1985), "whatever their social rank, in the eyes of the law women were second-class citizens" (p.57). Therefore, women were susceptible to dangers such as sexual and physical threats. Also, most women were portrayed as fallen women, old maids, or victims of social circumstances. This situation led them into slavery even at an early age (Rashed \& Shahwan, 2018).

In essence, one of the problems in the Victorian age was women's inferiority in many aspects. In this regard, women were hardly seen in literary works (Soumia, 2015). Despite women's detrimental situations, some feminine writers

\footnotetext{
* Corresponding author: isyaku87@gmail.com
} 
appeared to publish their literary works under pseudo names. One of these writers was Marry Evans. She sent one of her literary works to Charles Dickens to check it before it was published but under the name of George Eliot (Ramsdell, 2018). Afterward, Dickens wrote Eliot a letter clarifying his philosophical admiration because of some womanly touches in Evans' literary text. Therefore, Dickens was never in doubt that George Eliot, the pseudo name, was a woman.

I have been so strongly affected by ... the book you have had the kindness to send me ... I hope you will excuse my writing to you to express my admiration of their extraordinary merit ... If I had been left to my own devices, to address the said writer as a woman. I have observed what seem to me to be such womanly touches, in those moving fictions, that the assurance on the title-page is insufficient to satisfy me ... If they originated with no woman, I believe that no man ever before had the art of making himself, mentally, so like a woman since the world began (Hartley, 2012, p.331).

Within fifty years, many significant declarations appeared. Maslow (1970) asserted that it is astonishing how little the empirical sciences have to offer on the subject of love. Additionally, Lernout (2006) suggested that researchers in the field of comparative literature are rare today. In this regard, Sinclair (2016) also concluded that compassion has received little attention over the past quarter-century. In all of this, this paper comes out to enrich the field of comparative literature, particularly, Eliot's Middlemarch and Dickens' Hard Times have hardly been studied in terms of psychological compassion based on the Seven-Stage Model of Maslow's Motivation Theory.

The foregoing explanations encouraged us to investigate the similarities and differences between feminine and masculine novelists' techniques in revealing the insight natural expressions of compassion. Specifically, this paper explores psychological compassion as expressed by Dorothea in Eliot's Middlemarch and Louisa in Dickens' Hard Times based on the Seven-Stage Model of Maslow's (1970) Motivation Theory. Additionally, this paper shows how the findings of this investigation reinforce or refute the Victorian masculine stereotypical mottos that women could not express more than half of life and could not feel a passion. By employing the Seven-Stage Model, this paper will serve as a powerful guideline for students, academicians, and researchers in analyzing protagonists' feelings, emotions, behaviours, and motivations in the literary texts to conduct similar studies that can be used for academic purposes.

\section{LITERATURE REVIEW}

Some recent literary studies related to the theme of this study have been conducted, focusing on previous research on Eliot's Middlemarch and Dickens' Hard Times.

\section{A. Eliot's Middlemarch}

A few studies analysed certain related concepts in Eliot's Middlemarch. For instance, a study conducted by Anderson (2018) focused on analyzing the concepts of individuality and marriage by clarifying the romantic relationship between Dorothea and Casaubon in Middlemarch. The author concluded that Dorothea escapes from the romantic world and cannot associate with it. Also, Nijibayashi (2015) explored romanticism and the influence of John Ruskin on George Eliot's Middlemarch. The study concluded that Dorothea's only failure is her marriage to Casaubon. Similarly, Weber (2012) studied discussed the continuity of married companionship in Middlemarch. According to Weber, Eliot's insistence on the ordinariness of wedded women's tears suggested the contemporary ethical challenges that would examine relationships that very consistently produce suffering.

\section{B. Dickens' Hard Times}

Some previous studies explored related concepts in Dickens' Hard Times. For instance, Wiggins (2017) revealed marriage and unionization that bring security at home and work and that mirror each other in their futility in Hard Times. The author inferred how the father exploits the innocence of his daughter and marries her to a wealthy old man for financial benefits without considering her feelings and emotions. Additionally, Bansal (2016) revealed that Hard Times devoid of warmth and love because it was a persistent tussle between fact and fancy. The author concluded that a woman is losing her selfhood, property, and immersing her identity in that of her brother and her husband. Also, Awawdeh (2010) explained that Dickens criticized the social and moral abuses in the Victorian age through unsuccessful marriages of some main characters. The study suggested that human relations and economic relations have been contaminated.

\section{MASLOW’s SEVEn-Stage Models}

The Seven-Stage Models was developed by Abraham Maslow (1901-1970). Maslow was an American psychologist who was best known for his Hierarchical Triangle of Needs that was published in 1940. He proposed that satisfaction of needs was influenced by an individual's behaviour and motivation to feel satisfied with the achievement of the needs. Besides, Maslow suggested that human behaviour was determined by the tendency of individuals to achieve goals. In 1970, he proposed that all individuals had needs that were organized in a hierarchical triangle. This hierarchical triangle works from the lower level called Physiological Needs to the higher level called the Self-Actualization Needs. He argued that individuals should have to satisfy the basic and primary level completely to move higher to the next upper levels in the hierarchy. This paper employs the expanded model which is called Seven-Stage Model. This model has 
two extra levels: Cognitive Needs and Aesthetic Needs. The first extra level, Cognitive Needs, shows that human beings need to understand what is going on around them, whereas Aesthetic Needs suggests that human beings need beautiful imagery that is aesthetically pleasing to continue up towards Self-Actualization.

Furthermore, Maslow's Hierarchical Needs consist of seven needs, namely; physiological needs, safety needs, love and belonging needs, self-esteem needs, cognitive needs, aesthetic needs, and self-actualization needs. Based on the conceptual expressions of the Seven-Stage Models, this paper analyses psychological compassion in Eliot's Middlemarch and Dickens' Hard Times. To construct love, individuals have to fulfil all the conceptual expressions of the Models (Maslow (1970). They have to fulfil, satisfy and gratify all the conceptual expressions completely to reach the ultimate level, which is Self-Actualization needs. This paper includes an analysis of text and context that relates to compassion. Specifically, Maslow's Seven-Stage Model was used to analyze heroines' personalities in the selected novels.

\section{PSychological COMPASSiOn In MiddlemarCH AND HaRd Times}

The Seven-Stage Model of Maslow's Motivation Theory is employed to provide a comprehensive reading and obtain an understanding of the personalities of Dorothea and Louisa in Eliot's Middlemarch and Dickens' Hard Times respectively. Expansively, Maslow (1970) stated that individuals have needs and these needs are prioritized in a certain hierarchy. An individual must satisfy the primary needs to achieve higher needs in the hierarchy. This paper analyses psychological compassion in the selected novels based on Maslow's Hierarchical Needs as follows.

\section{A. Psychological Needs}

Maslow (1970) explained that this level includes basic life needs that aim to keep the individual alive, such as drink, food, water, shelter, clothing, and sleep. In Middlemarch, Eliot writes that Dorothea "was taking her usual place in the pretty sitting-room" (Eliot, 1872, p.6) and that she "walked about the house with delightful emotion" (Ibid. p.57). These expressions show that Dorothea lives a rich life. So, Dorothea has a complete family and a proper house to sleep and rest. She has enough food and drink. According to all the above clues, Dorothea fulfils, satisfies, and gratifies her physiological needs completely. In a similar vein, Louisa in Dickens' Hard Times lives in a rich house with her family because her father, Thomas Gradgrind, is a wealthy professor. Dickens writes "[Louisa] Her own private sitting-room was a story higher, at the window" (Dickens, 1854, p.127). Because of the wealthy' life, Louisa does not face problems in fulfilling her physiological needs. The above contexts indicate that both Dorothea in Eliot's Middlemarch and Louisa in Dickens' Hard Times fulfil and gratify all the conceptual expressions of the first lower-level of Maslow's Hierarchical Needs, which is called Physiological Needs. Now, Dorothea and Louisa can progress higher to the next level, which is called Safety Needs.

\section{B. Safety Needs}

Maslow (1970) proposed that an individual has to feel secure and comfortable. He added many extra conceptual expressions that are associated with safety needs, such as family, social and economic stability, physical safety, protection, security, health and wellness, as well as freedom from threats. In Eliot's Middlemarch, Dorothea's family, health security, and social stability manifest when she admires Ladislaw's good humour, and Ladislaw was admired by her personality. Eliot states "she had now a life filled ... with a beneficent activity which she had not the doubtful pains of discovering and marking out for herself" (Eliot, 1872, p. 671). From this expression, Dorothea feels comfortable with her life. Of course, she has no problem with this need because she fulfils it completely. In the same way, Louisa in Dickens' Hard Times feels safe in physical safety and economic security, which may be categorized as safety needs. Louisa's father protects her by keeping her up within his philosophy. He blames his children for observing some activities at the circus because he believes that all the circus' activities are a kind of imagination. Louisa says "we were peeping at the circus ... and father caught us" (Dickens, 1854, p.19). At the end of the novel, Louisa considers her father as the final and the only place to return if she has critical situations; she says "father ... I know I have been your favorite child. I know you have intended to make me happy (Ibid, p.253). From the above explanations, Dorothea and Louisa have no problem in terms of safety needs.

\section{Love and Belonging Needs}

The need for love and belonging was a necessity that encourages individuals to have friends, love, and affection towards family and others. This need represents a natural desire to be fulfilled by us as humans. Each individual must have a feeling of wanting to love and be loved, adore and be adored (Maslow, 1970). In Eliot's Middlemarch, Dorothea has two romantic relationships: one with Casaubon and the other with Ladislaw. Eliot showed that Dorothea plans to build a romantic relationship, "I should wish to have a husband who was above me in judgment and in all knowledge" (Eliot, 1872, p.30). Likewise, Ladislaw clarified his honest admiration, "her large eyes were fixed dreamily on a streak of sunlight" (Ibid, p.152). In other words, Eliot enhanced her work with many romantic glimpses that are raised distinctly in every Dorothea's meeting with her lovers. Of course, Dorothea fulfils and satisfies completely her needs of love and belongingness. On the other hand, in Dickens' Hard Times, because of her father's system of teaching, "teach these boys and girls nothing but facts" (Dickens, 1854, p.1), Louisa never learns how to love and what is love in her real-life? Additionally, it is hard to find any signs that expound any romantic glimpses between Louisa and both of her 
lovers, Bounderby and Harthouse. It is important to notice, too, that her brother confirms that his sister "never had a lover" (Ibid, p.167). Meanwhile, Bounderby remarks, “your daughter don't properly know her husband's merits" (Ibid, p.239). According to the above statements, Louisa does not fulfil and satisfy the level of love and belonging needs completely.

\section{Esteem Needs}

Maslow (1970) asserted that individuals should have recognition, admiration, and esteem from surrounding people to move to the self-esteem level which involves confidence, achievement, independence, competence, etc. In Eliot's Middlemarch, Eliot concurs with Maslow when Dorothea received appreciation from many surrounding people. For instance, Mr. James clarifies his admiration, recognition, and glory of Dorothea's beauty, "(Casaubon) is not half fond enough of Dorothea; and he ought to be, for I am sure no one else would have had him-do you think they would? I always thought it a horrible sacrifice of your sister, said Sir James" (Eliot, 1872, p.228). Continually, for confidence, achievement, independence, and competence, she shows her self-esteem when, "she had given up position and fortune to marry Will Ladislaw" (Ibid, p.671). According to these expressions, Dorothea fulfils and satisfies the esteem needs fully. On the contrary, Louisa in Dickens' Hard Times, losses her brother, husband, lover, and her romantic world. For instance, her husband does not care about her feelings and emotions because he considers her as a piece of his property. This lack of care means that Louisa's husband never appreciates her emotionally and romantically. Also, Louisa does not have the ethically justified ability to exchange her respect or feelings towards her husband. At the end of the novel, Louisa's husband clarified, "your daughter doesn't properly know her husband's merits" (Dickens, 1854, p.194). Back to her father's educational ideology, "Facts alone are wanted in life" (Ibid, p.1). Louisa also losses appreciation from the surrounding people like her brother who shows his harsh relationship with her because of his self-love and selfishness. He discovers the weaknesses of his sister's married life to another lustful man without a care for his family's duties. According to the above excerpts, Louisa does not fulfil and satisfy the level of esteem needs completely.

\section{E. Cognitive Needs}

Maslow (1970) articulated that humans have a strong need to understand what goes on around them. Therefore, he added another extra level with many associated expressions such as the desire for intelligent knowledge, understanding, self-awareness, and curiosity. In Eliot's Middlemarch, Dorothea affirms to improve her personality within society to show her full understanding of the right decisions in critical situations, particularly after her first husband dies. She explores the reasonable causes that lead to developing her character, "I should learn to see the truth by the same light as great men have seen it by" (Eliot, 1872, p.20). Her self-awareness urges her to understand all people around her by discovering their hidden passions and reaching a deeper level of intelligent knowledge, "all her eagerness to know the truths of life" (Ibid, p.5). However, Dorothea gratifies this level precisely. On the other hand, Louisa in Dickens' Hard Times adheres only with her father's cruel educational ideology which depends on fact rather than imagination, love, and emotion, "Facts alone are wanted in life" (Dickens, 1854, p.1). In this respect, Louisa cannot understand people's feelings and emotions romantically. At the end of the novel, she escapes from all surrounding people and returns to her father's house to ask him about love, imagination, and emotions, "where are the sentiments of my heart? What have you done, oh, Father, what have you done with the garden that should have bloomed once?" (Ibid, p.246). She feels that she can never explore, understand, or become aware of the right situation. Again, Louisa does not fulfil the level of cognitive needs perfectly.

\section{F. Aesthetic Needs}

Maslow (1970) mentioned that humans need beautiful imagery that is aesthetically pleasing, such as beauty, pride, creativity, and art. This level stimulates the five bodily senses to evoke a pleasurable emotional response that promotes positive affirmation of oneself and identity. In Middlemarch, Eliot enriches her novel with many aesthetic glimpses that are developed between lovers. For instance, Ladislaw expresses his admiration for Dorothea's beauty, "her large eyes were fixed dreamily on a streak of sunlight which fell across the floor" (Eliot, 1872, p.158). Similarly, because Dorothea realizes that her beauty is described by other people's senses, she makes her beautiful fashion, "the solicitudes of feminine fashion appear an occupation ... with a keen interest in gimp and artificial protrusions of drapery ... she was enamoured of intensity and greatness" (Ibid, p.4). However, Dorothea fulfils and satisfies the conceptual expressions of the aesthetic needs completely. On contrary, Louisa in Dickens' Hard Times does not know how to declare her inner emotions because her upbringing depends on facts that are far from certain aspects such as love and imagination. According to Bansal (2016), Hard Time "is a gripping narrative ... devoid of warmth and love; a persistent tussle between fact and fancy; life and mechanization" (p.1). Generally, it is hard to find any aesthetic needs in Louisa's life, and therefore she cannot satisfy the conceptual expressions of the aesthetic needs perfectly.

\section{G. Self-Actualization Needs}

Maslow (1970) suggested that an individual ought to reach the full potential of growth and achievement in his/her actual life. In Eliot's Middlemarch, Dorothea's previous satisfied needs provide her with a chance to arrive at the seventh level, which is self-actualization that has been commonly interpreted as the full understanding of the individuals' potential, power, and efforts. For all the events experienced by Dorothea, the last need that must be realized 
is self-actualization. Her first unemotional marriage that passes through her life makes her become a better human being completely. She wants to prove that she could recover from the unemotional marriage. With all her abilities and efforts, she wants to make up her second romantic relationship for her next comfortable life by truly becoming an ideal woman.

Moreover, Eliot narrates that the power of love, tenderness, and affection are exploded between Dorothea and Ladislaw honestly. She declares profoundly that "her soul thirsted to see him. How could it be otherwise?" (Eliot, 1860, p.432). In this light, she decides to lose her first husband's fortune. Also, she is never anxious about her future with Ladislaw and never looking for faults, weaknesses, or reveal physical and psychological shortcomings in his character. At the end of the novel, Eliot tacitly illustrates, "Dorothea has a little boy" (Ibid, p.672), which means that sexuality is satisfied without being stated obviously. After she has engaged with Ladislaw, Eliot remarks on her inner emotions which are full of admiration and appreciation towards Ladislaw, "her soul thirsted to see him" (Ibid, p.432). Furthermore, she considers her second marriage as a victory that removes all her worst past stories. These excerpts show that Dorothea satisfies all the conceptual expressions effectively.

In Dickens' Hard Times, on the other hand, it is worthy to recognize that it is hard to find any improvement in Louisa's personality because she rarely attempts to express her feelings and emotions. At the beginning of her romantic life, Louisa cannot understand and recognize the real meaning of marriage, "what are the Facts of this case? ... What do you recommend, father? asked Louisa" (Dickens, 1854, p.112). This queries mean that she is prevented from developing her compassion, imagination, and kindness because of her father's useless educational ideology of teaching, "facts alone are wanted in life ... Stick to Facts" (Ibid, p.1). Her brother clarifies that Louisa "never had a lover" (Ibid, p.167). After she has married, her relationship with her husband is one of the most tragic examples in her life because she was married to a worthless character. So, both Louisa and Bounderby do not have any romantic glimpses. In other words, Louisa "never cared for old Bounderby" (Ibid, p.152) emotionally or romantically. Unfortunately, Louisa does not have the full strength to have the equitable way of education to acknowledge the surrounding world which is made up of both fact and love.

\section{CONCLUSION}

This paper explored psychological compassion in Eliot's Middlemarch and Dickens' Hard Times with a particular focus on Dorothea and Louisa. The analysis was based on the Seven-Stage Model of Maslow's Motivation Theory (1970). According to the analysis, Dorothea's character was described as strong, resilient, responsible, and able to accept reality and love for herself and her family. She did not give up easily on any problems and events that happened. In the most difficult conditions, she tried to fulfil her basic needs as a human being. However, Dorothea fulfils, satisfies, and gratifies all the conceptual expressions of Maslow's Seven-Stage Model. This outcome means that Eliot concurs with Maslow's vision that individuals who satisfy all the conceptual expressions of the Seven-Stage Model are capable of love.

On the other hand, although Louisa in Dickens' Hard Times only fulfils the first two levels of hierarchical needs, she could not fulfil various other needs properly, particularly the conceptual expressions of the last five levels in the SevenStage Model. So, Louisa does not fulfil, satisfy, and gratify all the conceptual expressions of Maslow's Seven-Stage Model. This outcome means that Dickens does not concur with Maslow's vision that individuals who satisfy all the conceptual expressions of the Seven-Stage Model are capable of love. Therefore, because heroines in Eliot's Middlemarch fulfil, satisfy, and gratify all the conceptual expressions of the model distinctly, they harmonize correctly with Maslow's vision (1970) that those who have reached self-actualization are capable of love. Also, this conclusion clarifies that psychological compassion in Eliot's Middlemarch contributes to the refutation and criticism of the Victorian masculine stereotypical mottos that women could not express more than half of life and they could not also feel a passion.

\section{REFERENCES}

[1] Anderson, P. (2018). Evolving constructions of love and marriage in Austen, Eliot, and Wilde. Ph.D. dissertation, Florida State University.

[2] Awawdeh, S. (2010). Social relationships in Hard Times. Hebron University. https://www.academia.edu/3673683/social_relationships_in_hard_times (accessed 30/4/2021).

[3] Bansal, H. (2016). No way out: Issues of marriage and divorce in Dickens's Hard Times. Spring Magazine on English Literature, 2. 1, 1-5.

[4] Dickens, C. (1854). Hard Times. https://drive.google.com/file/d/1R2v7IEQKI5ITBElLgVjn9SQqocnpdCai/view (accessed 21/2/2021).

[5] Eliot, G. (1872). Middlemarch. https://drive.google.com/file/d/1GU9-20d0m3XSe7EkcRwZv8zqJsHJ1QoM/view (accessed $13 / 12 / 2020)$.

[6] Gallagher, C. (1985). The Industrial Reformation of English fiction: Social discourse and narrative form 1832-1867. The American Historical Review, 14. 1, 667-668. doi:10.1086/ahr/91.3.667

[7] Hartley, J. (2012). The selected letters of Charles Dickens. Oxford: Oxford University Press.

[8] Lernout, G. (2006). Comparative literature in the low countries. Comparative Critical Studies, 3. 1-2, 37-46. doi:10.1353/ccs.2006.0011

[9] Maslow, A. (1970). Motivation and personality (3rd ed.). USA: Collins, Harper \& Row. 
[10] Nijibayashi, K. (2015). Dorothea Brooke's political economy: Romanticism and the influence of John Ruskin on George Eliot's Middlemarch. Journal of Language, Literature and Culture, 62. 1, 19-31. d0i:10.1179/2051285615Z.00000000047

[11] Ramsdell, K. (2018). Encyclopedia of romance fiction. California: Greenwood, Inc.

[12] Rashed, T., \& Shahwan, S. (2018). What life was like for women in the late 1800. Humanities and Social Sciences Journal, 8. $20,44-47$.

[13] Sinclair, S., Norris, J., McConnell, S., Chochinov, H., Hack, T., Hagen, N., \& Bouchal, S. (2016). Compassion: A scoping review of the healthcare literature. BMC Palliative Care, 15. 1, 193-203. doi:10.1186/s12904-016-0080-0

[14] Soumia, S. (2015). Troubled Victorian femininity: George Eliot's The Mill on the Floss as a Case Study. Master's thesis, University of Oum-El-Bouaghi.

[15] Weber, C. (2012). The continuity of married companionship: Marriage, sympathy, and the self. Nineteenth-Century Literature, 66. 4, 494-530.

[16] Wiggins, B. (2017). All in the family: the natural ties and nurtured lies of family in Hard Times. https://www.academia.edu/32623600/All_in_the_Family_The_Natural_Ties_and_Nurtured_Lies_of_Family_in_Hard_Times (accessed 12/5/2021).

Ali M. Ali Alshwayyat is a $\mathrm{PhD}$ Candidate at the Center for English Language Studies, Faculty of Languages and Communication, Universiti Sultan Zainal Abidin (UniSZA), Terengganu, Malaysia. He researches psychological compassion in the novel literary genre.

Mohd Nazri L. Azmi is an Associate Professor of English at the Center for English Language Studies, Faculty of Languages and Communication, Universiti Sultan Zainal Abidin (UniSZA), Terengganu, Malaysia. His areas of research interest include literacy and comparative literature, second language acquisition, and language studies.

Isyaku H. is a Postdoctoral Researcher at the Center for Modern Languages and Communication, Faculty of Languages and Communication, Universiti Sultan Zainal Abidin (UniSZA), Terengganu, Malaysia. His areas of research interest include media linguistics, literary analysis, and language studies.

Khaled A. Hmoud Alamro is a lecturer in the Department of English Language and Literature, Faculty of Arts and Sciences, Middle East University, Amman, Jordan. His areas of research interest include literary analysis, language studies, and second language acquisition.

Mahameed M. is an Assistant Professor in the Department of English Language and Literature, Faculty of Arts and Sciences, Middle East University, Amman, Jordan. His areas of research interest include literary analysis, language studies, and second language acquisition.

Rashed Daghamin is an Assistant Professor of English at the University of Hail, Saudi Arabia. His research interests lie primarily in the area of poetry, contemporary literary theory, Palestinian literature, black literature, creative writing, postcolonial literature, and African American studies. 